\title{
Senators seek secure funds for research
}

[WASHINGTON] Supporters of science in the US Senate are set to introduce a new, longterm proposal for civilian research funding. They hope the measure will have brighter prospects than an existing plan - the National Research Investment Act, or S1305 - which would double such spending in ten years but has attracted the support of only 17 out of 100 senators.

Senators Bill Frist (Republican, Tennessee) and Jay Rockefeller (Democrat, West Virginia) may introduce the proposal as early as this week. It will propose that total funding for non-defence science and technology should grow each year by an amount that exceeds the rate of inflation - possibly by two per cent - and will also attempt to set a 'floor' below which the level of such spending will not fall.

Speaking at a meeting on Capitol Hill last week, Rockefeller repeated his warning that S1305 could not pass (see Nature 393, 4; 1998). He said that he and Frist would introduce an alternative that "wouldn't double [spending] but would look at a large amount of money".

The bill would include a basis for spending priorities, and also propose ways of mea-

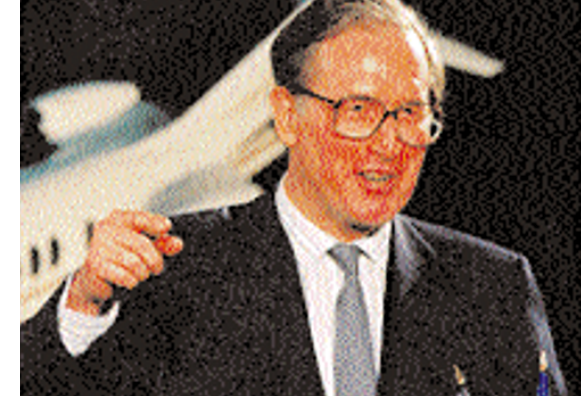

Rockefeller: 'viable' plan for more spending.

suring the efficiency of research programmes.

Science lobbyists say that the proposal could double the total annual investment of $\$ 34$ billion within 12 years, although the figures in it were still being revised late last week. They expect that Senate supporters of the earlier proposal - including Phil Gramm (Republican, Texas), Joseph Lieberman (Democrat, Connecticut), Jeff Bingaman (Democrat, New Mexico) and Pete Domenici (Republican, New Mexico) — will co-sponsor the new proposal.

The new bill will differ from $S 1305$ by giving only one figure for all science agencies, allowing some agencies to fare better than others. It will also include principles outlining how the money should be allocated, based on a document published last year by the Senate Science and Technology Caucus.

Backers of the proposal hope that the inclusion of these principles, together with the pledge to measure efficiency, will help to attract support for a companion measure in the House of Representatives. Frist and Rockefeller hope to get their measure passed quickly by the Senate Commerce Committee, although the prospects for it passing the full Senate this year do not look bright.

Like S1305, the new proposal is an authorization bill which would not assure annual funding for science, even if it is passed. But scientific societies see such a measure as an important means of expressing bipartisan support for science in the Congress, and influencing future years' budgets.

Bingaman, Lieberman and Rick Santorum (Republican, Pennsylvania) have introduced a similar measure that would authorize basic and applied research spending at the Department of Defense at two per cent above the rate of inflation for the next ten years.

Colin Macilwain

\section{Espionage verdict prompts call for retraction of polymerase paper}

[SAN DIEGO] A Californian biotechnology company has been found guilty of stealing research from a former junior laboratory researcher at the University at California at San Diego (UCSD), in a case of scientific espionage.

The researcher, Huguette Pelletier, is now at the Baylor College of Medicine in Houston, Texas. She is trying to achieve the retraction of an article on rat DNA polymerase $\beta$ - published in the journal Cell by researchers at the company in 1994 - because she believes it was based on the apparently pilfered research.

The dispute sets the stage for an intriguing, if rare, dilemma: how to balance the decision of the court with the scientific publication record.

A state court jury ruled last month that La Jolla-based Agouron Pharmaceuticals and a wife-and-husband team of its researchers - Michele A. McTigue and Jay F. Davies II - misappropriated the methodology to grow the crystal for a potentially valuable protein, rat DNA polymerase $\beta$. The jury said that Agouron should pay $\$ 200,000$ for the theft of trade secrets, and all the legal costs - estimated at $\$ 500,000$.

The Agouron article describing the crystallization of the enzyme that is believed to repair DNA was published in Cell on
25 March 1994. "I still want the paper retracted - that always has been my main goal," says Pelletier, a crystallographer who published her own more comprehensive article on the DNA polymerase $\beta$ in June 1994 in the journal Science.

Pelletier also continues to maintain that the Agouron scientists cannot scientifically support the research they published in their paper - an allegation that Agouron denies.

Benjamin Lewin, the editor of Cell, did not respond to either verbal or written questions submitted last week to the journal's office in Boston.

Repeated requests, beginning in 1994, that Pelletier made to Cell to address "scientific discrepancies" in the Agouron article have been rejected.

Despite the jury's decision, Agouron's spokeswoman Donna Nichols insisted that the Cell publication was valid research, performed independently from Pelletier's work. Neither Agouron nor its scientists had any plans to retract the article, she said.

Agouron and its scientists were stunned by the verdict, which Nichols rejected as a "ridiculous" decision reached by scientifically unknowledgeable people who "made the wrong decision". Neither of the two Agouron scientists would comment.

The company - best known for developing one of the protease-inhibitor drugs used against AIDS - has asked the judge to reject the verdict, and is seeking to appeal against the jury's ruling if the judge lets the decision stand.

Although the jury has found that the research was taken from a federally funded laboratory at UCSD, the university played no role in the case, having declined Pelletier's request to join with her in the legal case when it began four years ago. A UCSD spokeswoman declined to comment on the verdict, announced on 27 May.

The scientific theft occurred in the laboratory of Joseph Kraut, now a UCSD professor emeritus of biochemistry. Pelletier, McTigue and Davies all received their doctorates in Kraut's laboratory.

In testimony and court records, Pelletier's San Diego attorney, Daniel B. MacLeod, described McTigue as a scientific "mole who acted as a ferret", secretly seeking the latest techniques discovered by Pelletier in the Kraut laboratory to be transferred to Davies at Agouron.

Agouron had a team of nearly a dozen scientists working on the polymerase $\beta$ project in 1993-94, when the publicly traded firm injected more than $\$ 1.7$ million into an effort to create a 'blockbuster' drug to reduce the side-effects of anticancer medications. But the project proved unsuccessful and was abandoned. Rex Dalton 